\title{
Een stukje Gide, een stukje Proust: 'fidéliser le lecteur' in de Nouvelle Revue Française
}

SOPHIE LEVIE

'Fidéliser le lecteur', oftewel klantenbinding, was de functie van het feuilleton in de negentiende-eeuwse kranten en tijdschriften in Frankrijk en elders in Europa. Tot het arsenaal aan trucs dat werd ontwikkeld om de lezer zo ver te krijgen dat hij dag in dag uit de krant kocht om de lotgevallen van de helden en heldinnen die het feuilleton bevolkten te volgen, behoorden enerzijds technische procédés, zoals het knippen op de plek waar de spanning het hoogst was, en anderzijds een inhoudelijk repertoire, waarvan de strijd tussen goed en kwaad een vast ingrediënt vormde. De auteur was in dienst van de krant en diende zijn schrijversaspiraties ondergeschikt te maken aan de eisen van het publiek. Er was geen plaats voor reflectie, voor lange beschrijvingen, voor emancipatorische stellingnames of voor herkenbare politieke voorkeuren. De lezer diende tevreden worden gehouden via beschrijvingen van snelle actie, van herkenbare typen (het arme meisje; de slechterik; de doodgewaande erfgenaam), van onverwachte wendingen en van een flinke dosis (on)schuld, wraak, liefde en, uiteraard, een duel op zijn tijd.

In 1836 publiceerde La presse in twaalf afleveringen La vieille fille van Balzac, die er prat op ging in slechts drie nachten deze eerste Franse roman-feuilleton te hebben geschreven. 'Echte' schrijvers keken neer op het genre, dat een nieuw en ongeoefend leespubliek moest boeien. De minachting uitte zich via kwalificaties als 'lectuur', 'een knieval voor het publiek' en 'literatuurindustrie'. Er zijn legio voorbeelden bekend van de blunders die gerenommeerde auteurs als Tolstoj of Dickens in de haast maakten met betrekking tot uiterlijk en gewoontes van hun romanfiguren. En de vele anecdotes over de reacties van het publiek zijn stuk voor stuk amusant. Zo imiteerden de lezeressen van Anna Karenina op grote schaal de garderobe van Anna en vroeg men Tolstoj de weg naar het landgoed van Levin. Fraai is ook het verhaal over de Franse minister Duchatel, die naar het schijnt, op een goede morgen lijkbleek zijn ministerie kwam binnenwankelen en aan zijn medewerkers 
vroeg: is het waar dat La Louve (een van de personages uit Les mystères de Paris van Eugène Sue) dood is?

Het algemene beeld is dat de negentiende-eeuwse feuilletons spannende, maar slecht geschreven boeken opleverden; ondanks dat bezwaar zijn de populairste titels steeds herdrukt, vertaald, verfilmd en tot musical bewerkt. Het lijkt overigens verstandig niet alle romans die als feuilleton op de markt kwamen voor ze in boekvorm werden uitgegeven, over één kam te scheren. Dostojevski of Dumas père, George Sand of Karl May, Wilkie Collins of Théophile Gautier, over de stijl- en de kwaliteitsverschillen tussen deze auteurs is natuurlijk heel wat op te merken. Wat hun tomans, althans een deel daarvan, echter gemeen hebben is dat zij hun leven in stukjes begonnen zijn, met alle inhoudelijke en vormaspecten die daarbij horen. Dat is het overkoepelende kenmerk van het 'wordt vervolgd'-genre, dat getuige het succes van GTST en andere soaps nog niets van zijn populariteit heeft verloren.

In hun studie Der französische Feuilletonroman uit 1986 hebben Neuschäfer, Fritz-El Ahmad en Walter de jaren 1844, 1860, 1884 en 1912 als ijkpunten genomen. Uit deze vier jaren hebben zij de feuilletons in alle Parijse dagbladen onderzocht: 211 kranten, 743 auteurs en 1410 romans vormden hun werkterrein. Conform de aandachtspunten die rond 1980 de discussie in het letterkundig onderzoek hier en daar domineerden, letten zij in hun materiaal in het bijzonder op de wijze waarop de rol van de vrouw werd geschilderd, op de positie van de verschillende klassen en op sociaal-politieke vraagstukken in de onderzochte feuilletonwereld. Zij constateren op deze punten grote verschuivingen in het genre tussen 1844 en 1912 en ontkrachten daarmee het cliché dat de feuilletonroman een monolithisch en door onbeweeglijke patronen geregeerd genre zou zijn. In hun onderzoek hebben zij zich uitsluitend gericht op kranten, niet op tijdschriften, waardoor hun object dus uit die feuilletons bestaat die met dagelijkse regelmaat verschenen en niet uit proza dat in wekelijkse of maandelijkse porties aan het publiek werd opgediend.

De statistische bewerkingen die zij de vele gegevens hebben laten ondergaan, bieden naast de literair- en receptiehistorische informatie die hun onderzoek oplevert, een hoogst interessante blik in de wereld van de populaire literatuur, de rol van de negentiende-eeuwse media in de ontwikkeling van 
het lezen en het beroep van auteur. Het is opmerkelijk dat dit terrein, waarop een heel onderzoeksprogramma te formuleren zou zijn, twintig jaar na het verschijnen van deze studie voor het grootste deel nog op verdere ontginning wacht.

De Nouvelle Revue Française, het tijdschrift dat André Gide aan het begin van de twintigste eeuw oprichtte met een aantal gelijkgestemde vrienden, verscheen van 1909 tot het begin van de Eerste Wereldoorlog maandelijks in Parijs bij uitgeverij Gallimard. De steekwoorden waarmee het tijdschrift op grond van de uitlatingen van de oprichters en het resultaat van hun werk in de kritiek steevast is gekarakteriseerd, zijn puurheid, onbevangenheid, openheid en onafhankelijkheid. Een van de kwesties in het literaire leven waarover de NRF-redactie open, onbevangen, maar wel vol zorg discussieerde, was de status van de roman.

Gide en zijn tijdgenoten waren van mening dat het genre in moeilijkheden verkeerde en zij zochten, al experimenterend, naar wegen om uit de romaneske impasse te komen. Terwijl zij zich oriënteerden op de ontwikkelingen in het genre in en buiten Frankrijk om zich te laten inspireren in hun eigen romanpraktijk en zo de al dan niet bestaande crisis te helpen overwinnen, lieten zij echter tegelijkertijd in het tijdschrift zien dat er wel degelijk Frans kwaliteitsproza geschreven werd. In de NRF werden in de jaren tot de Eerste Wereldoorlog onder andere delen van de Recherche (Proust), Le grand Meaulnes (Alain-Fournier), La porte étroite en Les caves du Vatican (Gide), Fermina Marquez en Barnabooth (Larbaud) gepubliceerd; stuk voor stuk teksten die nu nog tot de belangrijkste gerekend worden die in die tijd in Frankrijk zijn verschenen. 'Fragments' en 'extraits' zijn de termen die in het tijdschrift door elkaar werden gebruikt om aan te geven dat het hier om voorpublicaties in feuilletonvorm ging. In sommige gevallen verschenen slechts één keer of enkele keren fragmenten, en werd de roman in zijn materialiteit als boek pas zichtbaar op het moment van zijn publicatie. Het kwam echter ook voor dat de tekst, voordat het boek uitkwam, uiteindelijk in zijn geheel toch eerst in het tijdschrift verscheen. Beide strategieën zijn bekend uit de negentiende-eeuwse praktijk en worden genoemd in de studie die hierboven kort is besproken. De gevolgen voor de tekst in alle stadia waarin delen aan een publiek werden voorgelegd in vergelijking tot het definitieve boek zijn de 
moeite van het bestuderen waard. In de NRF ging het om maandelijkse porties, hetgeen betekende dat de lezer bij iedere nieuwe aflevering een geheugensteuntje werd geboden in de vorm van een extreem korte samenvatting van het voorafgaande. Belangrijk is in ieder geval dat de NRF-groep van mening was dat een tijdschrift slechts dan haar lezers zou vinden als het 'grote romans' zou publiceren en dat volgende directies die opvatting hebben overgenomen.

In de periode 1914-1918 staakte het tijdschrift zijn verschijnen omdat een groot deel van de redactie en de potentiële auteurs bij de oorlog betrokken was. In 1919 begon het opnieuw en in dat jaar werd Jean Paulhan (18841968) benoemd in een tijdelijke functie met als opdracht het blad een grotere lezerskring te bezorgen. Paulhan, die na een vijftien jaar lange intensieve betrokkenheid bij de NRF in 1935 werd benoemd tot directeur van het tijdschrift, was zijn carrière begonnen in de organisatie en administratie van tijdschriften als Le spectateur en La vie contemporaine in de eerste jaren van de twintigste eeuw. De ontwikkeling van zijn inzichten met betrekking tot de samenstelling van ieder nummer, zijn pogingen om op allerlei manieren afwisseling aan te brengen in de structuur van de verschillende rubrieken, zijn aandacht voor nieuwe domeinen als de film, de grammofoonplaat, de music-hall en de wijze waarop hij de sectie 'kritiek' in het tijdschrift tot bloei bracht, zijn impliciet te volgen via de inhoud van de nummers van de NRF. Veel explicieter zijn Paulhans overwegingen en zijn permanente alertheid ten aanzien van de ontwikkeling van het tijdschrift te traceren via zijn gepubliceerde en ongepubliceerde correspondentie. Uit zijn brieven aan Gide, Mauriac, Ponge, Benda, Schlumberger en vele, vele anderen wordt duidelijk hoe hij zijn opvattingen voortdurend toetste aan die van zijn tijdgenotenauteurs en hoe hij steeds opnieuw bereid was zijn eigen visie op de meest geschikte koers voor het tijdschrift bij te stellen en te wijzigen. Ieder tijdschriftnummer diende een evenwichtig geheel te vormen en de compositie van de nummers werd door hem dan ook met de grootst mogelijke zorgvuldigheid verricht.

Paulhan was een voorstander van de 'littérature à suivre', dat wil zeggen, literatuur in beweging of populair, teksten die eigenlijk nog alle kanten op konden gaan. Het in stukjes knippen van romans die hij in aanmerking 
vond komen voor opname in de NRF, was een activiteit die hij graag beoefende. Niet iedere prozatekst was volgens hem daarvoor geschikt en hij heeft verschillende teksten die wel werden gepubliceerd bij uitgeverij Gallimard, en die hem werden aangeboden als mogelijk feuilleton, niet eerst in het tijdschrift willen opnemen. Een voorbeeld van een dergelijke als feuilleton geweigerde tekst is La nausée van Sartre. Maar Paulhan was, in tegenstelling tot veel collega's, wel degelijk een liefhebber van het feuilleton, en de continuering van de negentiende-eeuwse traditie in de NRF, die naar wij zagen door de oprichters in 1909 al was overgenomen, ging hem zeer ter harte. Gemakkelijk ging het niet altijd en het 'knippen' heeft hem veelvuldig verwijten opgeleverd, van 'pure barbarij' (Martin du Gard) tot 'U imiteert abstracte kunst. Toe maar, hak maar een kop of een borst af (Céline).

Paulhan redigeerde de feuilletons net zo zorgvuldig als de notities en er zijn dan ook allerlei voorbeelden te geven waaruit blijkt dat hij auteurs regelmatig voor de keus stelde: ofwel u gaat akkoord met de volgende inkortingen in dit hoofdstuk en deze manipulaties van uw tekst of de NRF kan uw proza niet gebruiken... Dikwijls was de reden plaatsgebrek, maar er waren ook tekst-intrinsieke factoren op grond waarvan een tekst niet in aanmerking kwam om zijn publieke leven te beginnen in feuilletonvorm. Jean-Paul Sartre's La nausée is een voorbeeld van een tekst die Paulhan niet geschikt achtte om in afleveringen te publiceren. Als reden liet hij de auteur weten dat de roman véél te lang was om in delen te verschijnen, het zou wel zes maanden duren en bij de tweede aflevering zou de lezer de draad al zijn kwijtgeraakt. Maar, zo troostte Paulhan Sartre toch, 'c'est admirable'. De lengte alleen kan het niet geweest zijn: waarom Proust en Gide wel in vele afleveringen, maar Sartre niet? Er moeten dus ook andere redenen zijn geweest waarom Paulhan Sartres roman niet in zijn tijdschrift wilde hebben.

Schrappen, knippen, verdoezelende puntjes, het behoorde allemaal tot de techniek van Paulhan. Hij wendde deze technieken overigens niet alleen aan in de redactie van fictionele teksten, maar evenzeer tijdens zijn bewerkingen van een rubriek als de 'chroniques artistiques', waarbij hij van de verantwoordelijke redacteur André Lhote de klacht kreeg dat deze zijn eigen tekst niet meer herkende nadat die door Paulhan onder handen was genomen.

De sterprozaïsten van de NRF in de eerste periode vervulden die rol ook 
in de jaren twintig. In 1919 plaatste het tijdschrift Albertine disparue (Proust) en La symphonie pastorale (Gide), in 1920 en 1921 fragmenten uit Si le grain ne meurt en de Recherche, in de volgende jaren meer Proust, meer Gide en teksten van Larbaud, Mauriac, Joseph Conrad, Giraudoux, Green, Duhamel, alles met de vermelding 'fragment' of 'pre-publicatie', en alles in feuilletonvorm.

In 1927 publiceerde Paulhan in de NRF in zes porties de Voyage au Congo, het reisverslag waarin Gide de wandaden van het kolonialisme aan de kaak stelt, in acht afleveringen Le temps retrouvé, het laatste deel van de Recherche, gepubliceerd na Prousts dood en in vieren La trahison des clercs, de roman in essayvorm waarmee Julien Benda zijn visie op intellectueel engagement presenteerde.

Het zijn deze pre-publicaties in feuilletonvorm die ik aan een nader onderzoek heb onderworpen, dat overigens nog niet is afgerond en waaruit hier dus slechts voorlopige conclusies zijn te trekken met betrekking tot de presentatie in het tijdschrift en in boekvorm. Vast staat dat de publicaties in het tijdschrift in ieder geval voorafgingen aan de editie in boekvorm. Gide en Proust verschenen bij Gallimard, Benda bij Grasset, dat wil zeggen bij de concurrent. Een eerste vergelijking van de teksten in het tijdschrift en in de boeken toont dat aan de lopende tekst in deze gevallen niet is gesleuteld. De teksten hebben dus integraal in het tijdschrift gestaan. Opmerkelijk is de omvang van de porties die de lezer kreeg voorgeschoteld: veertig bladzijden Gide was gebruikelijk, Proust ging in parten van vijftien tot dertig bladzijden en Benda's tekst vulde circa dertig bladzijden per keer. Het maandelijkse stukje Gide of stukje Proust was dus ook in omvang heel iets anders dan het feuilleton in de krant.

De vraag waarom er allerlei manipulaties hebben plaatsgevonden met hoofdstuktitels en nummering van de fragmenten moet vooralsnog onbeantwoord blijven. Was de tekst in een definitieve vorm al klaar of was de auteur nog aan het schrijven? De problematisering van het feuilletonbegrip, dat wil zeggen onderzoek naar verschillende reeksmatig gepubliceerde teksten lijkt een vruchtbaar terrein. Een vraag die daarbij in ieder geval aan de orde zou moeten komen is of dergelijke teksten per definitie als 'feuilleton'varianten mogen worden gezien, ook wanneer ze aanvankelijk niet als zodanig waren geconcipieerd en redactionele bewerking moesten ondergaan om geschikt te worden gemaakt voor deze publicatievorm? 
Tekstgenese is als onderzoeksmethode weer populair en de vergelijking van de verschillende stadia waarin de delen van deze romans verschenen met de definitieve versie zal een antwoord geven op deze en andere kwesties. Bij Gide en Proust levert een vergelijking van tijdschrift- en boektekst andere hoofdstuktitels op en bij Proust dan ook nog enkele malen een 'knip' die onnatuurlijk lijkt en die alleen maar gemotiveerd kan zijn geweest door ruimtegebrek. In het geval van Benda heeft het uitgebreide notenapparaat dat in de NRF onderaan de pagina's staat, in de boekuitgave allerlei wijzigingen ondergaan, bovendien staan de noten in het boek achterin. In het tijdschrift zijn allerlei buitentekstuele geheugensteuntjes voor de lezer aangebracht: bij iedere volgend deel van een van de drie teksten wordt aangegeven wanneer de voorgaande afleveringen in de NRF hebben gestaan. En na het 'FIN' aan het eind van het laatste stuk van de Voyage au Congo wordt de lezer door middel van een noot aangekondigd dat de tekst op korte termijn in boekvorm bij de 'Éditions de la N.R.F.' zal uitkomen en dat het volgende deel, de Voyage au Cameroun direct als boek zal verschijnen. Deze geheugensteuntjes zijn, zoals gezegd, te verklaren uit het feit dat het tijdschrift maandelijks uitkwam en dat de lezer een vorige aflevering moest kunnen terugvinden. Opmerkelijk is echter dat er bij de presentatie van dit proza geen tekstuele ingrepen lijken te zijn verricht waarbij in de tekst, of via een hoofdstuktitel een korte inhoud van het voorafgaande werd gegeven.

Deze eerste onderzoeksgegevens dienen te worden uitgebreid met meer materiaal en leiden idealiter tot overzichten die een literair-historisch belang hebben, zoals de lijsten die bij het Duitse onderzoek naar de Franse feuilletonroman zijn gevoegd.

Dat er ook met betrekking tot de feuilletons in de twintigste-eeuwse tijdschriften interessant onderzoek is te verrichten, staat echter wel vast. En ook al zijn de romans die in de NRF verschenen van een totaal andere aard dan het grootste deel van de populaire literatuur die in de negentiendeeeuwse kranten verscheen, de functie van beide was gelijk: 'fidéliser le lecteur'.

-> SOPHIE LEVIE promoveerde in 1988 aan de Universiteit van Amsterdam op een onderzoek naar het literaire tijdschrift Commerce. Sinds september 2001 is zij hoogleraar Algemene Literatuunwetenschap en Algemene Cultuurwetenschappen aan de Radboud Universiteit Nijmegen. 
LITERATUUR

- Laurence Brisset, La NR F de Paulhan. Parijs 2003.

- Martyn Cornick, 'Jean Paulhan's recipe for success at the NRF 1925-1940'. La revue des revues, nr. 8, 1989/1990, 11-20.

- Pierre Hebey, L'esprit NR F 1908-1940. Parijs 1990.

- Maaike Koffeman, Entre classicisme et modernité. La Nouvelle Revue Française dans le champ littéraire de la Belle Epoque. Amsterdam 2003.

- Hans-Jörg Neuschäfer, Dorothee Fritz-El Ahmad, Klaus-Peter Walter, Der französische Feuilletonroman. Die Entstehung der Serienliteratur im Medium der Tageszeitung. Darmstadt 1986. 